\title{
RASIONALITAS PARTAI POLITIK DALAM PENENTUAN CALON ANGGOTA LEGISLATOR LOMBOK TENGAH 2019
}

\section{AGUS \& ZAKARIA ANSORI}

\author{
UIN MATARAM
}

aguschandra.lombok@gmail.com | zakariaansori1@uinmataram.ac.id

\begin{abstract}
Abstrak
Penelitian ini bertujuan mengeksplorasi rasionalitas pimpinan partai politik dalam penentuan calon anggota DPRD, dengan membandingkan partai politik kovensional dan partai politik Islam.Untuk mendapatkan kedalaman informasi, penelitian mengambil studi kasus pemilihan DPRD Kabupaten Lombok Tengah tahun 2019.Eksplorasi fenomena dilakukan dengan mengunakan rational choce theory dari James S. Coleman (1994) dan teori modalitas dari Pierre Bourdieu (1930-2002). Metode penelitian yang digunakan adalah kualitatif deskriptif dengan pendekatan grounded theory. Hasil penelitian menunjukkan rasionalitas pimpinan partai politik dalam penentuan calon legislator pada Pemilu anggota DPRD, yakni biaya politik (political cost), peluang keterpilihan figur (electoral figure), ketersediaan dana (economic capital) calon, basis massa (social capital) calon, dan kuota perempuan sebgai pelaksanaan aturan Pemilu. Rasionaltas parta politik tersebut dipengaruhi oleh sistem Pemilu proporsionalitas terbuka.
\end{abstract}

Kata Kunci : Rasionalitas, Partai Politik, Calon Legislator

\section{A. Pendahuluan}

Pengalaman Indonesia melaksanakan Pemilu sudah berjalan sejak tahun 1955, namun Pemilu tahun 2019 merupakan Pemilu istimewa dalam sejarah politik Indonesia. Letak keistimewaan pemilu 2019 adalah merupakan pemilu pertama yang diselenggarakan secara serentak untuk pemilihan legislatif dan eksekutif.Pemilu anggota legislatif merupakan Pemilu untuk memilih anggota DPR, DPD, DPRD provinsi dan DPRD kabupaten/kota.Sedangkan Pemilu eksekutif merupakan Pemilu untuk memilih presiden dan wakil presiden.

Apabila Pemilu sebelumnya, kedua lembaga ini diisi melalui mekanisme Pemilu secara terpisah, sehingga negara dituntut mengeluarkan anggaran besar, maka guna menghadirkan Pemilu yang efisien namun tidak mengurangi legitimasi 
politik calon terpilih, pemerintah mengambil pilihan kebijakan penyelenggaraan Pemilu serentak. Pemikiran ini melahirkan Undang-Undang Nomor 7 Tahun 2017 tentang Pemilihan Umum.

Ada banyak sisi menarik dari Pemilu serentak tahun 2019.Misalnya, tentangrivalitas politik yang semakin tinggi. Tingginya rivalitas politik disebabkan oleh jumlah partai politik kontestan Pemilulebih besar dibandingkan Pemilu sebelumnya. Jika Pemilu tahun 2014 diikuti sebanyak 10 partai politik nasional, tahun 2019 bertambah menjadi 16 partai politik. Dilihat dari jumlah kursi yang diperbutkan, pada Pemilu 2019, untukkursi anggota DPR RI sebanyak 575 kursi, dengan jumlah calon anggota DPR. RI sebanyak 8.370 orang. ${ }^{1}$

Rivalitas politik yang tinggi tidak hanya terjadi di tingkat pusat, akan tetapi sampai di tingkat daerah. Argumentasi ini ditunjukkan dengan data sekunder yang memperlihatkan untuk Dapil Provinsi Nusa Tenggara Barat, jumlah anggota DPR RI yang diperebutkan partai politik pada tahun 2019 sebanyak 11 kursi, terdiri dari Dapil NTB I (satu) 3 kursi mencakup Sumbawa Barat, Sumbawa, Dompu, Bima, dan Kota Bima. Kemudian Dapil II (dua) 8 kursi mencakup Lombok Barat, Lombok Tengah, Lombok Timur, Lombok Utara, dan Kota Mataram. ${ }^{2}$ Untuk anggota DPRD Provinsi NTB, jumlah kursi dewan yang diperebutkan masih sama dengan Pemilu sebelumnya, yakni 65 kursi.Jumlah calon anggota DPRD yang berkontestasi sebanyak 917 orang (kpu-ntbprov.go.id).Sementara, di tingkat Kabupaten Lombok Tengah, jumlah kursi 50 kursi dengan jumlah calon anggota DPRD $667 .^{3}$

Adapun distribusi alokasi kursi anggota DPRD masing-masing Dapil di Kabupaten Lombok tengah, yaitu; Dapil 1 (Kecamatan Praya dan Praya Tengah) 10 kursi dengan 134 calon, tingkat persaingan 13,4 \%. Dapil 2 (Kecamatan Kopang

\footnotetext{
${ }^{1}$ Di kutip dari www.kpu.go.id, tanggal 11 Mei 2019

${ }^{2}$ Dikutip dari lampiran III Undang-Undang Nomor 7 tahun 2017 tentang Pemilihan Umum

${ }^{3}$ Dikutip dari laman KPU Lombok Tengah, kpu-lomboktengahkab.go.id
} 
dan Janapria) jumlah alokasi kursi 9, jumlah calon 116, tingkat persaingan 12,9 \%.. Dapil 3 (Kecamatan Pujut dan Praya Timur), jumlah alokasi kursi 9, jumlah calon 120, tingkat persaingan calon 13,3 \%. Berikutnya Dapil 4 (Kecamatan Praya Barat dan Praya Barat Daya) jumlah kursi 7, jumlah calon 100, tingkat persaingan 14,3 \%.. Dapil 5 (Kecamatan Jonggat dan Pringgarata), jumlah kursi 8, jumlah calon 103, tingkat persaingan 12,9 \%. Dapil 6 (Kecamatan Batu Kliang dan Batu Kliang Utara), jumlah kursi 7, jumlah calon 94, tingkat persaingan 13,4 \% (Dokumen Penetapan Dapil DPRD Pemilu Tahun 2019, KPU Kabupaten Lombok Tengah). Sedangkan rata-rata tingkat persaingan para calon DPRD Lombok Tengah pada Pemilu tahun 2019 berkisar dari 12,9 \% hingga 14,3 \%.

Berdasarkan data di atas, nampak tingkat rivalitas politik calon-calon anggota DPRD di Kabupaten Lombok Tengah cukup tinggi. Untuk menghadapi tingginya rivalitas politik tersebut, partai politik dituntut mempertimbangkan banyak aspek dalam penetuan calon anggota DPRD.Gejala ini semakin menguat mengingat fungsi idieologi tidak lagi menjadi rujukan masyarakat dalam memberikan suaranya pada Pemilu.Pengganti dari ideology partai dalam mempengaruhi pilihan masyarakat yakni kapasitaskandidat atau calon anggota DPRD.

Pergeseran fenomena kepartaian ini telah banyak diungkapkan oleh peneliti lain, seperti Prasetya yang menyebutkan bahwa di era reformasi telah terjadi kekaburan peran ideologi partai dalam pemilu sehingga tidak ada perbedaan yang ekstrim antara partai yang satu dengan partai yang lain. ${ }^{4}$ Penelitian lainnya seperti Srihardjono dan Mada5; Terakhir penelitian Mujani memang menyebut di negara-negara Asia khususnya Filipina dan Mongolia, faktor

\footnotetext{
${ }^{4}$ Yudhi Imam Prasetya, 2011, Pergeseran Peran Ideologi Partai Politik, (Jurnal Ilmu Politik dan Ilmu Pemerintahan, Vol.1.No.1,2011): hlm.39

${ }^{5}$ Srihardjono, Nanang Bagus \& Yakobus Mada,Proses Rekrutmen Calon Legislatif Partai Politik Kota Malang 2009, diterbitkan oleh JISIP : Jurnal Ilmu Sosial dan Ilmu Politik, ISSN: 2442-6962, Vol.2,No.2hlm 44 (2013)
} 
ekonomi berpengaruh terhadap konsolidasi demokrasi, tetapi faktor budaya politik, seperti latar belakang tradisi dan agama tidak memberi pengaruh. ${ }^{6}$

Penelitian ini berbeda dengan penelitian-penelitian di atas.Tulisan ini memiliki orientasi untuk membongkar rasionalitas pimpinan partai politik dalam penentuan calon anggota DPRD.Pada aspek ini penulis memandang, disamping faktor-faktor personal calon sebagai modalitas politik yang diperhitungkan partai politik sebagaimana temuan Srihardjono dan Mada, Prasetya, serta Mujani di atas.Pada pemilu Tahun 2019, di Kabupaten Lombok Tengah pimpinan partai juga memperhitungkan faktor-faktor non-personal calon, seperti ekonomi dan jaringan sosial calon.

\section{B. Partai Politik dan Sistem Pemilu}

Secara etimologis, Maurce Duverger, menyebutkan bahwa kata partai politik berasal dari bahasa Latin 'pars’, artinya ‘bagian`’. Pengertian kata partai politik dari Duvreger tersebut, oleh Muhadam Labolo dan Teguh Ilham dimaknai bahwa di dalam suatu negara yang demokratis, idealnya tidak boleh hanya ada satu partai politik, melainkan harus banyak partai politik ${ }^{8}$.

Menurut Asshiddiqie, partai politik merujuk pada golongan sebagai pengelompokkan masyarakat berdasarkan kesamaan tertentu, seperti tujuan, ideologi, agama, bahkan kepentingan. Pengelompokan masyarakat, dapat dilihat dari organisasi secara umum, seperti organisasi kemasyarakatan, organisasai keagamaan, organisasi kepemudaan, serta organisasi politik.Asshiddiqie kemudian menyatakan, dalam perkembangannya, partai politik diasosiasikan untuk

\footnotetext{
${ }^{6}$ Mujani, Saiful, Konsolidasi Demokrasi: Sebuah Tes Model Ekonomi Politik, Jurnal Ilmu Politik, Vol.22, No.1, hlm vii (2017)

${ }^{7}$ Maurice duverger, 1984, partai politik dan kelompok-kelompok penekan, bina aksara, Jakarta hal:5

${ }^{8}$ Labolo, Muhadam \& Teguh Ilham, 2015, Partai Politik dan Sistem Pemilihan Umum di Indonesia: Teori, Konsep dan Isu Strategis, Depok, PT.Rajagrafindo Persada, hal:9
} 
organisasi politik, yaitu organisasi masyarakat yang bergerak dibidang politik ${ }^{9}$. Selanjutnya Sigmund Neumann dalam Fadjar, mendefinisikan partai politik sebagai berikut;

“organisasi artikulatif dalam masyarakat, terdiri dari mereka yang memusatkan perhatiannya pada pengendalian kekuasaan pemerintahan dan yang bersaing untuk memperoleh dukungan rakyat, dengan beberapa kelompok lain yang mempunyai pandangan yang berbeda-beda"10.

Dalam undang-undang nomor 2 tahun 2008 tentang partai politik, definisi partai politik adalah organisasi yang bersifat nasional dan dibentuk oleh sekelompok warga Negara Indonesia secara sukarela atas dasar kesamaan kehendak, dan cita-cita untuk memperjuangkan dan membela kepentingan politik anggota, masyarakat, bangsa dan Negara, serta memelihara keutuhan Negara Kesatuan Republik Indonesia berdasarkan Pancasila dan Undang-Undang Dasar Republik Indonesia Tahun 1945.

Partai politik memiliki sejumlah fungsi, tetapi Heywood menyebutkan fungsi utama partai politik yakni menyeleksi dan menyediakan bagi negara para pemimpin partai politik mereka untuk digunakan sebagai pemimpin lembagalembaga negara ${ }^{11}$.Dalam undang-undang nomor 2 tahun 2008 tentang partai politik. Pasal 11 Ayat (1) menyebtkan fungsi partai politik, yakni; (a) pendidikan politik bagi anggota dan masyarakat luas; (b) penciptaan iklim yang kondusif bagi persatuan dan kesatuan bangsa; (c) penyerap, penghimpun, dan penyalur aspirasi politik masyarakat dalam merumuskan dan menetakkan kebijakan Negara; (d) partisipasi politik warga negara; (e) rekrutmen politik dalam proses pengisian jabatan politik.Terlaksananya fugsi-fungsi partai politik dalam negara demokrasi dipengaruhi oleh bekerjanya system Pemilu yang dipilih negara

\footnotetext{
${ }^{9}$ Asshiddiqie, Jimly, 2005, Kemerdekaan Berserikat, Pembubaran Partai Politik dan

Mahkamah Konstitusi, Jakarta, Konstitusi Press, hal:31

${ }^{10}$ Fadjar, Abdul Mukthie, 2012, Partai Politik Dalam Perkembangan Ketatanegaraan

Indonesia, Malang Setara Pressn hal:4

${ }^{11}$ Ibit hal 300-410
} 
bersangkutan.Sistem Pemilu yang diterapkan negara-negara di dunia terbagai dalam dua rumpun yakni; single-member constituency(system distrik) dan multimember constituency (system proporsional). ${ }^{12}$

Sistem distrik merupakan sisitem pemilu dengan prinsip satu distrik (daerah pemilihan) memilih satu wakil tunggal (single-member constituency) atas dasar suara terbanyak.Sistemproporsional merupakan system pemilu dengan prinsip satu distrik memilih beberapa wakil (multi-member constituency).Dengan demikian, perbedaan pokok antara kedua sistem ini adalah terletak pada cara menghitung perolehan suara menjadi kursi, atau dikenal dengan cara mengkonversi suara rakyat menjadi kursi di parlemen.

\section{Rasionalitas Partai Politik dalam Menentukan Calon Legislator}

Menurut Richard S Katz Dan William Crotty (2014), rekrutmen calon anggota DPRD merupakan proyek partai politik yang paling penting, karena dua alasan. Pertama, rekrutmen calon merupakan tahapan yang dilalui partai untuk memutuskan siapa orang yang akan diajukan untuk dipilih oleh pemilih pada saat pemilihan berlangsung. Dalam sistem pemilu di Indonesia, pemilih tidak memiliki pilihan alternatif selain yang disodorkan oleh partai, maka kualitas calon anggota DPRD berada pada otritas partai politik.Kedua, rekrutmen calon merupakan tahapan yang memiliki kontestasi (rivalitas) paling tinggi pada internal partai politik, karena sistem pemilu yang menggunakan sistem proporsional terbuka dengan konversi suara terbanyak akan menentukan langsung siapa di antara orang yang ada dalam daftar calon sebagai pemenang pemilihan dan duduk di kursi DPRD, sekaligus tingkat ravilitas calon dalam internal partai ikut memberi andil pada perolehan suara komulatif partai politik.

Dalam norma Pemilu yang berlaku, sistem pemilu menempatkan pimpinan partai politik sebagai pemilik tunggal otoritas penetapan daftar bakal calon

${ }^{12}$ Miriam Budiardjo, Dasar-Dasar Ilmu Politik, Edisi Revisi (Jakarta, PT.Gramedia Pustaka Utama, 2010), hlm.461 
anggota DPRD, secara berjenjang. Ketentuan ini disebutkan dalam UndangUndang Nomor 7 Tahun 2017 tentang Pemilu dan Undang-Undang Nomor 2 Tahun 2008 tentang Partai Politik.

Pada sisi yang lain, secara teoritik idealnya partai politik memperhatikan tiga faktor dalam proses penentuan atau rekrutmen calon anggota legislator. Ketiga faktor tersebut yakni norma dalam AD/ART partai politik, sistem pemilu yang di atur undang-undang pemilu, dan budaya politik yang berlaku di masyarakat. Dalam pandangan Katz dan Crotty mengatakan, ketiga faktor ini menjadi prosedur minimalis pimpinan partai dalam merekrut calon anggota legislator.

Fakta politik Pemilu 2019 di Lombok Tengah menunjukkan, partai politik mengabaikan pendekatan-pendekatan ilmiah seperti keharusan moral untuk mematuhi ketentuan dalam AD/ART, tetapi justru menggunakan celah dalam undang-undang pemilu dan undang-undang prtai politik sebagai jalan pintas memuluskan capaian kepentingannya untuk memenangkan pemilihan sebagai rasionalitas tindakan. Pilihan-pilihan partai politik ini mengesankan gejala pragmatisme politik lebih dominan dibandingkan etik politik.Rasionalitas pragmatis ini muncul karena partai politik membutuhkan calon yang banyak untuk mendapatkan suara pemilih yang semakin banyak. Pada sisi yang lain, kandidat membutuhkan partai politik sebagai persyaratan administasif menjadi calon anggota legislator. Dalam konteks tersebut, relasi pimpinan partai politik dan calon anggota legislator merupakan relasionalitas berbasis rasionalitas instrumental.Fenomena ini memperkuat penjelasan teoritis dari Max Weber tentang hirarki rasionalitas tindakan manusia.

Realitas lain dari Pemilu legislatif tahun 2019 di Kabupaten Lombok Tengah menunjukkan, ada dua basis rasionalitas pimpinan partai politik dalam rekrutmen calon anggota legislator yakni tuntutan pemilih dan tuntutan keuangan. 
Perilaku pemilih pragmatis atau pemilih ekonomi sebagaimana penjelasan mazhab ekonomi yakni kecenderungan perilaku pemilih yang memilih kandidat dengan rasionalitas matrial menyebabkan biaya politik yang harus dikeluarkan partai politik menjadi tinggi. Dalam menjawab karekteristik pemilih yang demikian, rasionalitas pimpinan partai politik dalam menentukan calon anggota legislator, yakni political cost dan electoral figure,economic cavital, social cavital.Dalam kontestasi pemilu partai politik juga berusaha mematuhi koridor undangundang.Dalam undang-undang Pemilu disebutkan ada keharusan partai politik mengajukan kuota $30 \%$ calon perempuan dari seluruh daftar calon dalam suatu daerah pemilihan.Untuk melaksanakan ketentuan undang-undang Pemilu, pimpinan partai mempertimbangkan faktor kuota perempuan.

\section{Political Cost danElectoral Figure}

Partai politik lahir dengan tujuan mendapatkan kekuasaan di lembaga pemerintahan. Realitas politik ini sejalan dengan sumbangan pemikiran Sigmund Neumann menyebutkan; partai politik sebagai organisasi artikulatif dalam masyarakat, terdiri dari mereka yang memusatkan perhatiannya pada pengendalian kekuasaan pemerintahan dan yang bersaing untuk memperoleh dukungan rakyat, dengan beberapa kelompok lain yang mempunyai pandangan yang berbeda-beda.

Pemikiran Neumann di atas ingin mengatakan bahwa setiap partai politik, apapaun basis ideologinya, memiliki tujuan yang sama yakni bersaing untuk memperoleh dukungan rakyat dalam pemilu agar bisa menduduki jabatan politik di pemerintahan. Tujuan partai politik pada Pemilu anggota legislator Kabupaten Lombok Tengah tahun 2019 kemudian adalah bersaing memperbutkan suara rakyat untuk mendapatkan 50 kursi di DPRD Kabupaten Lombok Tengah. 
Tujuan partai politik sebagaimana dijelaskan oleh Neumann menjadi rasionalitas pimpinan partai politik dalam penentuan calon anggota legislator.Fenomena rasionalitas pimimpinan partai politik ini diperkuat oleh James Coelman sebagai penggagas teori rationalitas choice, yang menyebutkan bahwa orang bertindak secara sengaja ke arah suatu tujuan.Maka mendapatkan suara rakyat untuk mendapatkan kursi di DPRD sebagai tujuan, menjadi fokus utama pikiran pimpinan partai politik dalam dalam menentukan calon anggota legislator.

Untuk mencapai tujuan mendapatkan kursi di parlemen, pemilu tahun 2019 memiliki kompetisi tinggi, sehingga membutuhkan banyak sumber daya politik.Pimpinan partai politik menyadari sumber daya politik yang memiliki peran dominan adalah finansial untuk pembiayaan politik (political cost) partai.Rata-rata partai politik menghadapi dua kondisi menjelang kontestasi Pemilu 2019.Pertama, partai tidak siap menyediakan pembiayaan politik dalam menghadapi Pemilu.Kedua, partai selalu mengalami erosi figur yang disebabkan banyak faktor, salah satunya figur partai pindah ke partai yang lain yang mereka sebut sebagai "politisi lompat pagar". ${ }^{13}$

Mudahnya perpindahan figur partai politik ke partai politik lain disebabkan oleh tidak adanya filter dari undang-undang Pemilu maupun undang-undang partai politik. Undang-undang Pemilu misalnya hanya menyebutkan syarat untuk menjadi calon anggota DPR atau DPRD menjadi anggota partai politik.Tidak ditentukan berapa batas minimal seseorang menjadi anggota dalam suatu partai politik untuk dapat menjadi calon anggota legislator dari partai bersangkutan.Sementara itu, setiap orang yang maju menjadi calon anggota legislator ingin menang dalam Pemilu. Maka jika berdasarkan kalkulasi politiknya, seseorang berpeluang terpilih lebih besar

${ }^{13}$ Wawancara dengan H.Fuad Ketua DPD I Partai Golkar, tanggal 12 Juli 2019 di Kantor DPRD Kabupaten Lombok Tengah 
pada partai politik lain dibanding pada partai politiknya sendiri, dia akan berpindah ke partai politik lain tersebut. ${ }^{14}$

Kondisi kepolitikan dan kepartaian di atas, mendorong pimpinan partai politik mencari instrumen-instrumen tindakan politik. Dalam kadar yang lebih maju, instrument-instrumen itu menjadi orientasi tindakan politik pimpinan partai. Pemikiran Max Weber seorang ahli sosiologi berkebangsaan Jerman relevan untuk menjelaskan fenomena politik tersebut.

Dalam teorinya tentang tindakan sosial, Weber menegaskan terminologi tindakan sosial sebagai perilaku manusia ketika dan sejauh agen atau para agen, melihatnya sebagai hal yang bermakna secara subjektif.Kata Weber semua individu pada dasarnya memiliki orientasi tindakan, tugas analis sosial dan politik kemudian menafsirkan orientasi tindakan manusia. Weber kemudian membagi orientasi tindakan manusia secara hirarkhis menjadi empat, sebagai berikut;

a) Tradisional, merupakan orientasi tindakan yang paling dasar, yakni tindakan yang berasal dari kebiasaan, tindakan ini banyak dilakukan dalam kehidupan sehari-hari

b) Afektual, merupakan tidakan yang ditentukan oleh emosi, perasaan, ungkapan perasaan sang aktor.

c) Nilai-rasional (wertrational), merupakan tindakan yang dilakukan secara sadar oleh suatu kepercayaan pada nilai khusus demi nilai itu sendiri.

d) Rasional secara instrumental (zweckrational), merupakan tindakan yang dilakukan dengan terlebih dahulu memperhitungkan dan mempertimbangkan makna, tujuan, dan konsekuensi-konsekuensi. ${ }^{15}$

Karekteristik sosial orang sasak seperti jika berkunjung ke orang lain atau kelompok lain membawa "buah tangan" atau oleh-oleh, merupakan tindakan social tradisional atau tindakan yang orientasinya kebiasaan. Perkembangan selanjutnya dari kebiasaan membawa oleh-oleh ketika

${ }^{14}$ Wawancara dengan Zaeoni, SH, Ketua Divisi Hukum KPU Kabupaten Lombok Tengah, tanggal 14 Juli 2019

${ }_{15}$ Michel M. Harmon dan Richard T. Mayer, Teori Organisasi Untuk Administrasi Publik (Kreasi Wacana, 2014), hlm.100 
berkunjung atau kebiasaan dibawakan oleh-oleh dari orang yang berkunjung menjadi ungkapan perasaan atau cara para agen menyampaikan perasaan terima kasih atau saling menghormati. Tindakan ini berkembang menjadi nilai-rasional

Kondisi kepartaian di atas mendorong psikologi politik pimpinan partai menempatkan ketersediaan political cost danelectoral figure sebagai komponen yang diperhitungkan dalam penentuan calon anggota legislator. Setidaknya calon yang dipilih oleh pimpinan partai politik adalah orang yang secara finansial mampu menyediakan biaya politik untuk partai. Rasionalitas political cost dan electoral figure diperkuat oleh pernyataan ketua partai DPC partai GERINDRA;"belajar dari pengalaman Pemilu 2014 dan gejala mentalitas pemilih yang masih sangat pragmatis, rapat-rapat di internal partai kami menyimpulkan bahwa agar partai bisa mendapat kursi yang maksimal, maka partai membutuhkan biaya politik. Maka dalam menentukan calon kami pertimbangkan komitmen calon untuk membiayai opersaional partai dalam perjuangan di Pemilu, mereka juga harus memiliki elektabilitas yang tinggi. Jadi kedua faktor ini bagi kami sama-sama penting dipertimbangkan"16

Data di atas menunjukkan fenomena bahwa dalam penentuan calon anggota legislator, pimpinan partai politik memperhitungkan political cost danelectoral figure. Fenomena poltik ini diperkuat oleh pemikiran Pierre Bourdieu modal ekonomi, yakni sumber daya yang bisa menjadi sarana produksi dan sarana finansial, seperti alat-alat produksi (mesin, tanah, buruh), materi (pendapatan dan benda-benda), dan uang.

Pada fenomena Pemilu 2019, sebagai proses memenuhi kebutuhan biaya politik partai, pimpinan partai politik mempertimbangkan komitmen calon anggota legislator untuk membiayai operasional politik partai.

${ }^{16}$ Wawancara dengan Muhdar, Ketua DPC Partai Gerindra Kabupaten Lombok Tengah, tanggal 10 Juli 2019, bertempat di rumah kediaman Muhdar di Jontlak, Praya Tengah 
Metodenya, tidak memberlakukan secara merata besaran komitmen tersebut, karena ada pertimbangan lain. Untuk calon anggota legislator perempuan misalnya, pimpinan partai tidak memberi target komitmen tertentu karena undang-undang mengatur kuota $30 \%$ calon perempuan wajib dipenuhi partai politik.Permasalahan di Pemilu 2019, partai mengalami kesulitan mendapatkan calon anggota legislator perempuan.Maka, perempuan mendapatkan perlakuan istimewa dari partai poitik.

Disamping itu, ada beberapa figur yang secara finansial kurang memiliki uang, namun dia memiliki basis sosial pemilih yang kuat atau di sebut electoral figure.Misalnya karena orang tersebut merupakan elit informal yang memiliki karisma di masyarakat. Di antara mereka adalah ustadz, tuan guru, pimpinan ormas, tokoh adat, dan lain sebagainya. Pertimbangan pimpinan partai politik terhadap figur ini di ungkapkan oleh Ketua DPC PBB;"saya memasang Alimudin, S.Ag di Dapil satu karena kalkulasi politik waktu itu, Alimudin merupakan ustddz yang memiliki pengaruh di Praya Tengah terlebih di Kelurahan Gerantung dan Desa Batunyala. Dan ini terbukti hasil Pemilu memang memperlihatkan Alimudin memiliki suara yang signifikan sebagai penyokong suara partai, dia berada diperolehan suara nomor dua setelah saya, padahal Alimudin merupakan pemain baru di politik, dia tidak pernah menjadi calon anggota legislator sebelumnya"17

Data di atas menunjukkan ada pertimbangan electoral figure dari calon anggota legislator sebagai basis rasionalitas pimpinan partai dalam penentuan calon anggota legislator. Konsep ini diperkuat oleh pemikiran Pierre Bourdieu tentang modal sosial, yaitu jaringan hubungan sebagai sumber daya untuk penentuan kedudukan sosial.

\footnotetext{
${ }^{17}$ Wawancara dengan Lalu Muh. Arif Ketua DPC PBB Kabupaten Lombok Tengah, tanggal 4 JUli 2019, bertempat rumah dikediaman Lalu Muh. Arif
} 


\section{Economic Cavital}

Salah satu modalitas politik yang diperkenalkan oleh Bourdieu yakni modal ekonomi.Terminlogi modal ekonomi yang digagas Boudieu adalah sumber daya yang bisa menjadi sarana produksi dan sarana finansial, seperti alat-alat produksi (mesin, tanah, buruh), materi (pendapatan dan bendabenda), dan uang.

Sifat pemilu sebagai aktivitas yang melibatkan massa membutuhkan ketersediaan modal ekonomi yang cukup. Ada dua komponen biaya yang harus tersedia dalam kotestasi partai, yakni; (1) biaya operasional proses organisasi partai politik sebagai peserta pemilu di KPU; (2) biaya operasional pemilih. Biaya operasional organisasi partai meliputi; operasional kantor dan kepengurusan organisasi partai, operasional administrasi anggota partai sebagaimana dipersyaratkan oleh undang-undang, dan biaya operasional tim internal partai dalam proses verifikasi keanggotaan oleh KPU. Sedangkan biaya operasional pemilih meliputi; spanduk, baliho, stiker, atribut partai, operasional untuk tim pemenangan partai, konsumsi dan transpaortasi massa yang dikumpulkan partai, iklan kampanye partai.

Pemilu 2019 sebagai Pemilu yang paling berat selama beberapa kali Pemilu di era reformasi.Masa kampanye yang panjang yakni selama delapan bulan menyebabkan kebutuhan biaya politik menjadi tinggi.Demikian halnya dengan perilaku pemilih yang semakin pragmatis menambah beban ekonomi partai semakin berat.Efek dari semua situasi politik yang demikian menyebabkan pimpinan partai memperhitungkan kemampuan modal ekonomi (economic cavital) yang dimiliki seorang bakal calon dalam penentuan calon anggota legislator.Fenomena di atas mengemuka dalam diskusi dengan beberapa ketua partai yang mengatakan;tidak ada pimpinan partai politik yang tidak memperhitungkan kemampuan modal ekonomi yang dimiliki bakal calon untuk diajukan sebagai calon oleh partai politik.Kami di partai Gerindra menempatkan factor kemampuan ekonomi calon sebagai yang utama, karena 
partai tidak menyediakan anggaran biaya politik untuk calon.Sementara masyarakat taunya kalau ada calon anggota legislatif datang pasti bawa uang, barang, atau materi lainnya.Yang penting kita sampaikan secara terbuka kepada bakal calon.Kami memang membuka biaya pendaftaran dan baiaya untuk penentuan nomor urut. Semua partai politik melakukan hal yang sama, yang berbeda hanya nama penarikan uangnya saja. Ya ini memang menjadi fakta politik kita tahun ini ${ }^{18}$.

Data di atas menunjukkan kebutuhan partai terhadap biaya politik menyebabkan semua partai politik baik partai politik nasionalis maupun partai politik Islam menarik uang pendaftaran dan pendaftaran nomor urut bagi calon. Fenomena ini dikemukakan oleh salah satu calon anggota legislator dari Partai BERKARYA; saya pernah punya pengalaman di partai politik Islam yakni PKB tahun 2014, dan kemarin untuk pemilu 2019 ini kembali ditawarkan oleh PKB. Tapi saya menolak karena uang yang dimina sebagai biaya pendaftaran terlalu banyak.Sementara di PKB persaingan untuk bisa menang cukup tinggi, maka saya memilih tawaran dari Partai Berkarya.Jadi kalau soal pertimbangan kemampuan ekonomi calon, semua partai menggunakan kalkulasi itu, tidak peduli ideologinya ${ }^{19}$.

Pandangan di atas memperkuat teori modalitas yang dipaparkan oleh Bourdieu yakni modal ekonomi.Terminlogi modal ekonomi yang digagas Boudieu adalah sumber daya yang bisa menjadi sarana produksi dan sarana finansial, seperti alat-alat produksi (mesin, tanah, buruh), materi (pendapatan dan benda-benda), dan uang.Tapi rasionalitas pimpinan partai yang demikian tidak berdiri sendiri, namun dipengaruhi oleh karekteristik perilaku pemilih

\footnotetext{
${ }^{18}$ Wawancara dengan H.Muhdar Ketua DPC Partai Gerindra Kabupaten Lombok Tengah, dilaksanakan di Jontlak, Praya Tengah (rumah yang bersangkutan), pada hari Sabtu tanggal 3 Agustus 2019, jam 19.00 s/d 21.00 WITA

${ }^{19}$ Wawancara dengan Iwan Harsono, calon anggota DPRD terpilih daerah 1 (PrayaPraya Tengah) dari Partai Berkarya. Wawancara dilaksanakan di rumah kediaman yang bersangkutan hari Sabtu tanggal 24 Agustus 2019
} 
pragmatis sebagaimana dijelaskan oleh mazhab ekonomi.Mazhab ini menyebutkan individu cenderung bertindak rasional, yaitu memaksimalkan keuntungan yang diperoleh dari tindakannya dan meminimalkan efek negatif dari tindakan yang dilakukan tersebut.Dari sini kemudian mashab ini menegaskan bahwa manusia merupakan mahluk rasional dan bertindak berdasarkan pada pertimbangan untung-rugi (ekonomi).

\section{Social Cavital}

Meskipun seseorang memiliki modal ekonomi yang kuat, atau dia juga seorang incumbent, dan di dukung oleh organisasi masyarakat (ormas), tapi tidak menjamin seseorang tersebut diperhitungkan oleh pimpinan partai dalam penentuan calon anggota DPRD. Pimpinan partai politik juga menghitung secara cermat modalitas social yang dimiliki oleh seseorang untuk didaftarkan sebagai calon anggota legislator.

Kelebihan kepemilikan modal sosial seorang calon menjadi kalkulasi politik pimpinan partai dalam penentuan calon, karena tuntutan partai politik untuk mendapatkan suara sebanyak mungkin dalam kontestasi Pemilu.Maka apabila seseorang lemah dalam modal ekonomi, namun menjadi perioritas pimpinan partai apabila seseorang tersebut memiliki modalitas social yang kuat.

Modalitas sosial merupakan modalitas yang muncul dari kepercayaan masyarakat pemilih kepada calon anggota legislator. Untuk mendapatkan kepercayaan masyarakat, politisi membutuhkan waktu yang cukup lama, karena kepercayaan dari masyarakat lahir melalui proses yang panjang. Sebagaimana dikemukakan oleh anggota legislator terpilih dari partai BERKARYA;Untuk mendapatkan kepercayaan dari masyarakat memerlukan waktu bertahun-tahun.Metode yang saya lakukan untuk mendapatkan kepercayaan dari masyarakat saya lakukan dengan sering mengunjungi masyarakat dengan cara-cara informal. Saya bertemu dengan pedangang kaki 
lima, mendengar permaslahan mereka, dan memberikan solusi. Saya bantu mereka dalam bentuk yang kecil-kecil tetapi sesuai dengan kebutuhan mereka. Hasilnya efektif untuk mendapatkan suara, beberapa desa yang saya tidak kunjungi pada masa jadwal kampanye ternyata saya dapat suara.Setelah saya telusuri ternyata karena beberapa tahun yang lalu saya sering dating ke desa bersangkutan, berbincang dengan mereka, dan memberikan bantuan atas kebutuhan mereka tanpa berbicara tentang politik.Interaksi saya dengan masyarakat yang sudah bertahun-tahun yang lalu masih melekat dipikiran mereka ketika mereka memberi pilihan politik. ${ }^{20}$

Menurut Iwan Sutrisno, pimpinan Partai Berkayra memilihnya sebagai calon anggota legislator dan didaftarkan ke KPU Kabupaten Lombok Tengah, karena pimpinan partai mengkalkulasikan basis massa yang menjadi modal sosial yang saya miliki. Iwan Sutrisno merupakan politisi yang memiliki profesi pengusaha dan dipandang memiliki basis massa ril dan sudah melekat dengannya.4. Kuota Perempuan

Perempuan dalam politik electoral mendapatkan afirmatif policy melalui model pemberian kuota sekurang-kurangnya $30 \%$ mulai dari kepengurusan partai hingga daftar calon anggota DPR dan DPRD. Pada ranah kepengurusan, misalnya diatur melalui pasal 173 Ayat (2) huruf e undangundang nomor 7 tahun 2017, menyebutkan salah satu persyaratan yang harus dipenuhi oleh partai politik untuk dapat menjadi peserta Pemilu adalah menyertakan paling sedikit $30 \%$ keterwakilan perempuan pada kepengurusan tingkat pusat. Dalam pengusulan daftar bakal calon anggota DPRD juga harus memenuhi sekurang-kurangnya $30 \%$ keterwakilan perempuan.Ketentuan ini di atur dalam pasal 245 undang-undang nomor 7 tahun 2017.

${ }^{20}$ Wawancara dengan H.Iwan Sutrisno, Calon anggota DPRD terpilih dari Partai Berkarya. Wawancara dilaksanakan hari minggu tanggal 24 Agustus 2019, jam 19.15 sampai jam 22.00 WITA, bertempat dikediaman Kelurahan Renteng-Praya 
Ketentuan dalam undang-undang di atas, diterjemahkan pada Peraturan KPU secara lebih detail. Pasal 6 Peraturan KPU Nomor 20 tahun 2018, misalnya menyebutkan, bahwa daftar bakal calon anggota DPR dan DPRD yang disusun partai politik wajib memuat keterwakilan paling sedikit $30 \%$ perempuan setiap daerah pemilihan (dapil). Di dalam setiap 3 orang bakal calon pada susunan dapil, wajib terdapat paling sedikit 1 orang perempuan. ${ }^{21}$

\section{Kesimpulan}

Sistem Pemilu Proporsionaitas terbuka yang di atur dalam undang-undang nomor 7 tahun 2017 tentang Pmilihan Umum, dan pemetan perilaku pemilih yang dibagi menjadi tiga mazhab, yakni mazhab sosiologis, mazhab psikologis, dan mazhab ekonomi, menyebabkan rasionalitas pimpinan partai politik dalam penentuan calon legislator pada Pemilu anggota DPRD Lomok Tengah 2019 mempertimagkan aspek-aspek sebagai berikut; biaya politik (political cost)dan peluang keterpilihan figur atau kandidat (electoral figure), ketersediaan dana (economic cavital), basis masa(social cavital), dan kuota perempuan. Dari temuan penelitian ini, dirumuskan rekomendasi tentang perlunya reformasi sistem Pemilu, khususnya terkait sistem rekrutmen calon anggota legislator yang memberi kepastian karir politik bagi anggota partai.

${ }^{21}$ Pasal 6 Peraturan KPU Nomor 20 tahun 2018 


\section{DAFTAR PUSTAKA}

Asshiddiqie, Jimly, 2005, Kemerdekaan Berserikat, Pembubaran Partai Politik dan Mahkamah Konstitusi, Jakarta, Konstitusi Press, hal:31

Fadjar, Abdul Mukthie, 2012, Partai Politik Dalam Perkembangan Ketatanegaraan Indonesia, Malang Setara Pressn hal:4

Labolo, Muhadam \& Teguh Ilham, 2015, Partai Politik dan Sistem Pemilihan Umum di Indonesia: Teori, Konsep dan Isu Strategis, Depok, PT.Rajagrafindo Persada, hal:9

Maurice duverger, 1984, partai politik dan kelompok-kelompok penekan, bina aksara, Jakarta hal:5

Miriam Budiardjo, Dasar-Dasar Ilmu Politik, Edisi Revisi (Jakarta, PT.Gramedia Pustaka Utama, 2010), hlm.461

Mujani, Saiful, Konsolidasi Demokrasi: Sebuah Tes Model Ekonomi Politik, Jurnal Ilmu Politik, Vol.22, No.1, hlm vii (2017)

Peraturan KPU Nomor 20 tahun 2018

Srihardjono, Nanang Bagus \& Yakobus Mada,Proses Rekrutmen Calon Legislatif Partai Politik Kota Malang 2009, diterbitkan oleh JISIP : Jurnal Ilmu Sosial dan Ilmu Politik, ISSN: 2442-6962, Vol.2,No.2hlm 44 (2013)

Undang-Undang Nomor 7 tahun 2017 tentang Pemilihan Umum

Yudhi Imam Prasetya, 2011, Pergeseran Peran Ideologi Partai Politik, (Jurnal Ilmu Politik dan Ilmu Pemerintahan, Vol.1.No.1,2011): hlm.39

www.kpu.go.id

kpu-lomboktengahkab.go.id 